JERZY KOJKOŁ

$\stackrel{\odot}{\mid 1}$

\title{
TWARDOWSKI - RUBCZYŃSKI - HEMPEL. RELIGIA JAKO HUMANISTYCZNY ELEMENT MYŚLENIA O RZECZYWISTOŚCI SPOŁECZNEJ
}

\begin{abstract}
Jerzy Kojkoł, Twardowski - Rubczyński - Hempel. Religia jako humanistyczny element myślenia o rzeczywistości społecznej [Twardowski - Rubczyński - Hempel. Religion as a humanistic element of thinking about social reality], edited by Z. Drozdowicz, S. Sztajer ${ }_{\prime \prime}$ Człowiek i Społeczeństwo", vol. XXXIX, Poznań 2015, pp. 69-86. Adam Mickiewicz University Press. ISBN 978-83-232-2953-7, ISSN 0239-3271.
\end{abstract}

This article offers an interpretation of the views of three thinkers who represent theoretical approaches to the social functions of religion. These are: K. Twardowski, W. Rubczyński i J. H. Hempel. The discussed views, which are characteristic of Polish philosophy, emphasize the import_ance or religion and all kinds of faith for shaping a human being who is open to "Others" and shaping spirituality based on altruism. The authors presented in the article have the highest respect for outstanding people who do not abandon themselves to passions, focus on the matters most import_ant for the state, promote sound patriotism and reject political nationalism.

Jerzy Kojkoł, Akademia Marynarki Wojennej, Instytut Stosunków Międzynarodowych, ul. inż. Śmidowicza 69, 81-127 Gdynia, Poland

\section{Wstęp}

Celem artykułu jest interpretacja poglądów trzech myślicieli reprezentujących typowe dla polskiej filozofii społecznej stanowiska teoretyczne, zwłaszcza sposoby postrzegania roli religii w rzeczywistości społecznej, a także określenie kierunków badań, które należy systematycznie prowadzić, aby dopełnić obrazu polskiego myślenia o religii na początku XX wieku. 
Pierwsze lata ubiegłego wieku to okres gwałtownych sporów, silnej polaryzacji stanowisk i postaw. Każdy z wielkich problemów epoki - historia, społeczeństwo, jednostka, poznanie, moralność, religia, wychowanie próbowano rozwiązywać na wiele sposobów. W Polsce w tym czasie istniały różne filozoficzne nurty teoretyczne, które rozkwitły później, w okresie międzywojennym. Jak pisze Stanisław Borzym:

[...] ogólnie biorąc, filozofia międzywojenna ma charakter polifoniczny, charakteryzuje ją pluralizm postaw, ogromne zróżnicowanie orientacji. Poza szkołami lwowską i warszawską, z ich nastawieniem systematyczno-logicznym, rozwija się fenomenologia, tomizm. Powstały zręby nowych oryginalnych systemów filozoficznych, jak reizm Tadeusza Kotarbińskiego czy monadyzm St.I. Witkiewicza. Kontynuowano tradycję tzw. „filozofii narodowej” (Lutosławski). Marksizm rozwijał się poza obrębem filozofii profesjonalnej, przede wszystkim w zakresie filozofii kultury¹.

\section{Kazimierz Twardowski}

Początki tej różnorodności dostrzegamy jednak kilkanaście lat wcześniej. Ważne były w tym czasie postulaty teoretyczne myślicieli wywodzących się ze szkoły Kazimierza Twardowskiego, który przyjmował, podobnie jak kantyści i moderniści, że Bóg oraz jego stosunek do świata i człowieka nie może być przedmiotem wiedzy rozumowej, lecz jedynie wiary religijnej. Jego zdaniem filozofia nie może zajmować się tymi sprawami, gdyż znajdują się one poza jej możliwościami poznawczymi, związanymi przede wszystkim z naukami doświadczalnymi².

1 S. Borzym, Filozofia międzywojenna (1918-1939), w: A. Walicki (red.), Zarys dziejów filozofii polskiej 1815-1918, PWN, Warszawa 1986, s. 512. Por. K. Bochenek, L. Gawor, A. Jedynak, J. Kojkoł, Filozofia polska okresu międzywojennego. Zarys problematyki, Akademia Marynarki Wojennej, Gdynia 2013, s. 6; K. Bochenek, L. Gawor, M. Michalik-Jeżowska, R. Wójtowicz, Zarys historii filozofii polskiej, Wyd. Uniwersytetu Rzeszowskiego, Rzeszów 2013, s. 203; S. Borzym, Filozofia polska 1900-1950, Ossolineum, Wrocław - Warszawa - Kraków 1991, s. 97; J. Skoczyński, Modernizm i Młoda Polska, w: J. Skoczyński, J. Woleński, Historia filozofii polskiej, WAM, Kraków 2010, s. 393.

${ }^{2}$ Warto przytoczyć słowa K. Twardowskiego, który pisał: „Wyraz »filozofia« oznacza grupę nauk, podobnie jak wyraz »teologia« lub »przyrodoznawstwo«. Jak mówimy o naukach teologicznych lub przyrodniczych, tak mówimy o naukach filozoficznych. Trzeba zatem wskazać cechę wspólną, na podstawie której zaliczamy poszczególne nauki filozoficzne do jednej grupy umiejętności. Tą cechą wspólną jest pewna właściwość przedmiotów, które są nam dane albo wyłącznie w doświadczeniu wewnętrznym, albo zarów- 
Jan Woleński, analizując tę kwestię, stwierdza, że dla K. Twardowskiego filozofia jest nauką empiryczną, co oznacza, że powinna unikać wszelkiej spekulacji. Założyciel szkoły lwowsko-warszawskiej nazywał „metafizycyzmem” próby uzależniania konkretnych rozstrzygnięć filozoficznych od ogólnych poglądów w metafizyce. Nie miało przy tym dla niego znaczenia, czy była to metafizyka materialistyczna, czy spirytualistyczna. Zdaniem J. Woleńskiego opowiadanie się za taką lub inną metafizyką jest przedmiotem wiary, a nie wiedzy. Domagał się więc on radykalnego oddzielenia filozofii od religii i światopoglądu (także politycznego) 3 $^{3}$ W publikacji O filozofii średniowiecznej pisał:

Zapatrując się w ten sposób na rolę średniowiecza w dziejach ludów europejskich, zrozumiemy też, że to charakterystyczne dla tej epoki zespolenie wiary i wiedzy było skutecznym środkiem umożebniającym przeszczepienie wiedzy za pośrednictwem wiary z epoki starożytnej na ludy, które miały objąć kierownictwo duchowe Europy w epoce nowożytnej. Ale odkąd środek ten spełnił swój cel, stracił też swoje uprawnienie. Słusznie też epoka odrodzenia i humanizmu, idąc za głosem Okhama, oddzieliła wiarę od wiedzy, teologię od filozofii ${ }^{4}$.

Tym samym pojawił się problem stosunku nauki do wiary oraz teologii do filozofii. Szło o określenie ich wzajemnych relacji i przedmiotu badań. Średniowiecze zaczęło rozstrzygać ten dylemat na korzyść nauki, ale dopiero filozofia nowożytna ugruntowała pogląd, że filozofia i teologia oraz nauka i wiara nie stanowią żadnego jednolitego systemu. Nauka, której drogę wskazała filozofia, zajęła się przede wszystkim badaniem istoty i granic poznania, w szczególności rozumowego. Zdaniem K. Twardowskiego dość powszechnie uznano, że Bóg nie jest i nie może być przedmiotem filozo-

no w doświadczeniu wewnętrznym, jak i doświadczeniu zewnętrznym”. K. Twardowski, Psychologia wobec fizjologii i filozofii, „Przewodnik Naukowy i Literacki” 1/1897, s. 37.

${ }^{3}$ J. Woleński, Twardowski Kazimierz, w: Encyklopedia filozofii polskiej, t. 2, Polskie Towarzystwo Tomasza z Akwinu, Lublin 2011, s. 751. „Twardowski w zasadzie traktuje światopogląd jako zbiór opinii nienaukowych. Uważał jednak, że nie da się wykluczyć światopoglądu naukowego jako pewnego ideału, do którego konkretne światopoglądy mogą się zbliżać - z tego punktu widzenia można mówić - pisze J. Woleński - o systemach metafizycznych jako o wprawdzie nienaukowych, niemniej jednak przednaukowych zbiorach przekonań [...]. Należy wyraźnie podkreślić, że K. Twardowski bynajmniej nie lekceważył potrzeby i znaczenia światopoglądu w życiu człowieka [...]. Protestował także przeciwko narzucaniu komukolwiek światopoglądu”. J. Woleński, Filozoficzna szkoła lwowsko-warszawska, PWN, Warszawa 1985, s. 39.

${ }^{4}$ K. Twardowski, O filozofii średniowiecznej wykładów sześć, nakład H. Altenberga, Lwów 1910, s. 106 (pisownia oryginalna). 
fii ani nauki. Jest on jedynie przedmiotem wiary. Teologia powinna więc zajmować się tymi sprawami, które leżą „poza zakresem doświadczenia”.

Takie poglądy ukształtowały stanowisko K. Twardowskiego w kwestii statusu teologii. Podkreślał on, że z jednej strony jest ona dyscypliną badawczą, a z drugiej - stanowi jeden z czterech wydziałów uniwersyteckich. Mówiąc o teologii i jej miejscu w strukturze akademickiej, uznawał jej dopuszczalność jako rodzaj refleksji zajmującej się zagadnieniami wiary religijnej. Jego zdaniem teologia nie może wypowiadać się w kwestiach, o których decyduje rozum. Powinna być także oddzielona od nauk szczegółowych oraz od uniwersytetu.

W przeciwieństwie do teologii filozofia była dla K. Twardowskiego nauką empiryczną, uwolnioną od spekulacji i wpływów światopoglądowych. Jak zauważa J. Woleński:

[...] neutralność filozofii względem światopoglądu uważał K. Twardowski za warunek jej obiektywności. Tak rozumianą obiektywność traktował szerzej, odnosząc ją do całego życia uniwersyteckiego i akademickiego. Podkreślał, że uniwersytet musi być niezależny od władzy państwowej, choć ma prawo domagać się subsydiów ze strony rządu. Niezależność uniwersytetu od czynników politycznych uważał za jeden z gwarantów właściwego realizowania misji nauczycielskiej i badawczej5.

K. Twardowski nie uważał, że naukowiec może zrezygnować ze swoich przekonań religijnych czy światopoglądowych. Nie można go nazwać ateistą czy nawet agnostykiem. Boga pojmował on deistycznie, a nieśmiertelność duszy była dla niego istotnym elementem kultury chrześcijańskiej. Swoją wiarę uważał za sprawę prywatną, bez znaczenia dla filozofii. W ten sposób naukowiec - jego zdaniem - występuje w podwójnej roli, jako człowiek posiadający światopogląd i jako badacz, który swój światopogląd powinien przemilczeć. Warto zwrócić uwagę, że ta myśl mogła być także inspirująca dla filozofii polityki. Polityk był z jednej strony człowiekiem posiadającym światopogląd, ale na jego temat milczał jako osoba publiczna, z drugiej strony był działaczem politycznym i w sferze publicznej powinien starać się reprezentować całość społeczeństwa, a nie jedną grupę religijną. Każdy ma możliwość funkcjonowania w polityce, ale działania polityka powinny być zgodne z rozumem - mógłby konkludować K. Twardowski.

Działania takie musiały być podjęte, ponieważ zdaniem K. Twardowskiego stary świat „wali się” na każdym „polu pracy i myśli ludzkiej”.

5 J. Woleński, Twardowski Kazimierz, s. 751. 
Objawia się to chęcią porzucenia wszystkiego, co było, na rzecz tego, co wydaje się lepsze. Jego zdaniem do rzeczy, które trzeba „zmienić lub znieść”, zwolennicy naprawy świata zaliczają religię, w tym chrześcijaństwo. Jedni nie chcą jej zastępować niczym, twierdząc, że człowiek wykształcony nie potrzebuje żadnej religii, drudzy pragną zachować normy moralne wspólne dla wszystkich głównych wyznań, zakorzenione głęboko w ich sercach, odrzucić natomiast wszelki dogmatyzm teoretyczny.

[...] niepodobna przeczyć, iż życie religijne w warstwach oświeconych obumiera. Prostaki i dziś się garną do Boga i pod skrzydła Kościoła, ale ludzie „wykształceni” odwracają się od Kościoła, a nawet i od Boga [...]. Niezawodnie zaś jedna z tych przyczyn tkwi w usposobieniu przeważnej ilości tych właśnie, którzy są powołani do pielęgnowania pobożności i życia religijnego. Są to ludzie, więc ułomni, potrzebujący do pełnienia swych obowiązków w wyższym stopniu łaski Bożej, aniżeli ludzie w innych pracujących zawodach. Lecz nie wszyscy dbają należycie o tę łaskę; i dlatego nie wszyscy są zdolni do należytego pełnienia swych obowiązków. Trzeba więc choć w części przyznać słuszność tym, co przypisują winę upadku ducha religijnego, w pewnych kołach, urzędowym przedstawicielom religii. Ale było by niesprawiedliwością przypisać im największą część winy, a nie wejrzeć we własne serce, nie zbadać własnego sumienia i nie uznać, że i ludzie świeccy zawinili i zawiniają wiele złego ${ }^{6}$.

K. Twardowski był przeciwny zanikowi prawdziwej pobożności. Uważał, że zarozumiałość i fascynacja światem materialnym są największymi „przeszkodami do pobożności”. Obie przesłanki osiągają groźne rozmiary. Znikaniu pobożności w miarę rozwoju cywilizacji może zapobiec zrozumienie tradycji, dochodzenie do prawdy i tolerancja. Dotyczyło to zwłaszcza żydów. Odwoływał się przy tym do historii Jezusa Chrystusa, pisząc:

Jakiego wyznania był Chrystus? Mojżeszowego [...]. Nie tylko jako niemowlę Chrystus Pan się poddał przepisom zakonu Mojżesza, owszem i później, przez całe swe życie zastosowywał się do religii żydowskiej, nie tylko w strawie, mówiąc, iż nie przyszedł znieść zakazu, lecz wypełnić go, lecz i w czynie, uczęszczając do bożnic i pełniąc obrządki, jako prawdziwy kapłan wedle porządku Melchizedecha [...]. Nie przeciwko religii starozakonnej występował Chrystus Pan, lecz przeciwko fałszywemu jej pojmowaniu, przeciwko tym, co ją wypaczyli?

${ }^{6}$ Rozmyślania religijne na Nowy Rok, Dzień Trzech Króli, pierwszq, drugq i trzeciq niedzielę po Trzech Królach, luźne notatki, rękopisy IFiS PAN, syg. T’R 136 - T. 2, 3, s. 2 (pisownia oryginalna), http://rcin.org.pl [25.01.2015].

7 Ibidem, s. 3. 
K. Twardowski ubolewał, że wyznając wiarę, nie robimy tego z imieniem Chrystusa na ustach, a nazywamy ją katolicką, nie witamy się w imię Chrystusa, lecz padamy sobie do nóg, salonów naszych nie zdobi obraz Matki Boskiej i nie sławimy imienia Bożego w każdym miejscu. Wnioskował z tego, że moc imienia Chrystusowego słabnie i niknie. Uważał, że jest to spowodowane brakiem „gorącej wiary i ufnego przekonania” w obecność Chrystusa na ołtarzu. Krytykował zachowania ludzi w kościele, pisząc:

Wchodzi do Kościoła jejmość, strojna w jedwabie i drogie kamienie i ledwie skinąwszy głową wygodnie zasiada w ławie kościelnej. Czy jej możność tak postąpiłaby sobie tak samo, gdy weszła do izby, w której przebywa panujący? [...] Ile razy byłem świadkiem, że ludzie przed księdzem wychodzącym ze mszy św. wstają, oddając mu cześć, lecz wobec Chrystusa w sakramencie ołtarza [...] zachowują się biernie! ${ }^{8}$

Wydaje się, że w tych rozważaniach chodzi o ukazanie znaczenia religii, a w zasadzie wiary w dobrym wychowaniu człowieka, dla którego ważniejszy jest drugi człowiek niż on sam. Sądził, że wynika to z utraty prawdziwej pobożności skierowanej na Boga, a nie na księdza czy Kościół.

K. Twardowski podkreślał, że w czasach braku szacunku dla majestatu Bożego ludzie odmawiają należytego szacunku tym, którzy mają prawo go wymagać. Rośnie za to powaga wobec siebie samego, która staje się jedyną i najwyższą. Widać to w każdym stanie i wieku.

Dzieci tracą uszanowanie dla rodziców i nauczycieli, gdy dorosną i wstępują w jakikolwiek zawód, tracą uszanowanie dla swych przełożonych, żadnej nie mają powagi oprócz własnej, nikomu nie chcą być poddani, od nikogo nie chcą przyjmować choćby najżyczliwszego pouczenia; przeciw wszelkim zarządzeniom się buntują, niczyjej woli nie szanują, lecz dla własnej swej woli żądają zupełnej uległości. Daleki jestem od przemawiania za duchem serwilizmu, krzywdzącego godność osobistą człowieka. Każdemu przyznaję prawo własnego zdania i wolności przekonań, ale na wszystko jest czas i pora właściwa ${ }^{9}$.

Inne implikacje miały idee neomesjanistyczne, wywodzące się szczególnie z proromantycznych kręgów filozoficznych. Do tego rodzaju twórczości można zaliczyć pisma Wincentego Lutosławskiego, przyrównujące naród do nieśmiertelnego ducha przeobrażającego się w ciągłym rozwoju świadomości społecznej. W podobnym tonie pisał Witołd Rubczyński oraz inni przedstawiciele tego kierunku, m.in. Jacek Woroniecki.

8 Ibidem, ss. 5-6.

${ }^{9}$ Ibidem, s. 7. 


\section{Witołd Rubczyński}

Pogląd filozoficzne Witołda Rubczyńskiego odzwierciedlały jego postawę religijną. Sądził on, że nauka wraz z filozofią przedstawiają porządek panujący we wszystkich warstwach życia społecznego. Potwierdzają ostateczne źródło ładu, którym jest Absolut, oraz przybliżają człowieka do Boga ${ }^{10}$.

Przyjmował, że dzięki poznaniu docieramy do pozapodmiotowej rzeczywistości, na którą jego zdaniem składają się: „dziedzina wydarzeń fizyko-chemicznych, dziedzina ustrojów żywych, dziedzina twórczości umysłu, uczuć i woli”. Dziedziny te dowodzą, że we wszechświecie panuje porządek - ład, którego sprawcą ostatecznym jest wiekuista „Mądrość i Miłość”. W Filozofii życia duchowego podkreślał, że sfera ducha nie mogła rozwinąć się samoistnie ze sfery materii, zachęcał do pielęgnowania życia duchowego będącego jego zdaniem rękojmią prawdziwego postępu ludzkości, bronił poglądu o nieśmiertelności duszy, zwalczał przekonanie o wędrówce dusz, sądził, że podejmowanie w życiu i nauce zagadnień dotyczących świata fizycznego i moralnego w nieunikniony sposób prowadzi do poglądów metafizycznych. Jak słusznie zauważa Tomasz Knapik:

[...] autor podejmuje próbę obrony niezniszczalności ducha ludzkiego. Problem ten omawia konfrontując swoje poglądy, między innymi, z Bergsonem, Jamesem, a swoją tezę uzasadnia korzystając z doświadczeń psychologicznych ${ }^{11}$.

W filozofii W. Rubczyński wyróżniał metafizykę i etykę. Te dwie dziedziny miały jego zdaniem pełnić funkcję „pocieszycielską”, gdyż mogły wskazywać ludziom ład panujący w świecie, przeciwstawiający się chaosowi, destruktywnie oddziałującemu na rzeczywistość społeczną. Słusznie rekapituluje ten problem T. Knapik, pisząc:

${ }^{10}$ R. Palacz zaliczył jego filozofię do spirytualizmu. Zob. R. Palacz, Witold Rubczyński czyli filozofia polskiego spirytualizmu XIX wieku, w: idem, Klasycy filozofii polskiej, Zachodnie Centrum Organizacji, Warszawa - Zielona Góra 1999, ss. 279-284.

${ }^{11}$ T. Knapik, Kultura i wartości w ujęciu Witolda Rubczyńskiego i Floriana Znanieckiego, „Studia z Filozofii Polskiej”, t. 5, pod red. M. Rembierza, K. Ślezińskiego, Bielsko-Biała - Kraków 2010, s. 125. Por. W. Rubczyński, Filozofia życia duchowego jego wytrzymałość, skuteczność i ład w świetle doświadczenia i krytyki, Fiszer i Majewski, Poznań 1925, s. 710. O znaczeniu tej publikacji pisał T. Grabowski, Filozofia poznania i metafizyka prof. Rubczyńskiego, w: Przemówienia wygłoszone ku czci śp. prof. Witolda Rubczyńskiego dnia 15 listopada 1938 r., Kraków 1939, s. 10. 
Badając zagadnienia etyczne, Rubczyński czerpie z ducha chrystianizmu, tradycji kultury narodowej. Wierzy w potęgę narodu i państwa polskiego. Jednocześnie daleki jest od jakiegokolwiek nacjonalizmu ${ }^{12}$.

Zdawał sobie sprawę, że w epoce modernizmu i indywidualizmu nie może pominąć problematyki wolności, zastrzegał jednak, że musi być ona związana z szacunkiem dla przedmiotowego stanu rzeczy. Wolność jednostek i ład powszechny są sprzężonymi ze sobą ogniwami jednej religijnej całości ideowej.

Jego filozofia, nie odwołując się bezpośrednio do dogmatów, chciała dać równie trwały, lecz bardziej uogólniony obraz świata, będący czymś w rodzaju kompromisu między prawdami teologii a światopoglądem ludzi uprawiających naukę współczesną. W ten sposób jako jeden z pierwszych eksponował rolę sfery ducha w kształtowaniu rzeczywistości.

Podkreślał, że rzeczywistość nie rozwija się automatycznie. Zachęcał do budowania i pielęgnowania „ducha” jako najważniejszego elementu życia człowieka, stanowiącego rękojmię postępu ludzkości. Będąc pod dużym wpływem Augusta Cieszkowskiego oraz etyków młodopolskich, akcentował „moc i twórczą działalność ducha ludzkiego”. Stanisław Jedynak pisał:

[...] człowiek - zdaniem Rubczyńskiego - powinien włączyć się w proces tworzenia wartości dla ogółu, i to ogółu coraz większego, w którym rozwijałyby się ideały przyjaźni, braterstwa i konsekwentnego altruizmu. Altruizm taki uwzględniałby przede wszystkim duchowy rozwój jednostki ludzkiej ${ }^{13}$.

W. Rubczyński na szczycie hierarchii wartości umieszczał porządek całości wszechrzeczy. Z tej perspektywy starał się dostrzec harmonię dążeń jednostkowych i społecznych ${ }^{14}$.

${ }^{12}$ T. Knapik, Kultura i wartości..., s. 128. Warto także przytoczyć opinię Mirosława A. Michalskiego, który pisał, że W. Rubczyński był realistą, ale także „teistą - gdyż przyjmował, Boga - Stwórcę i Opatrzność, jeżeli chodzi o początek i stawanie się bytu. W obrębie zaś metafizyki, jeżeli chodzi o istotę bytu, był Witołd dualistą z akcentem spirytualistycznym. Przyjmował istnienie dwóch substancji: materialnej i duchowej, powstałych i zależnych od trzeciej substancji - substancji pierwszej - Boga”. M.A. Michalski, $\mathrm{Ku}$ idei Królestwa Bożego - myśl filozoficzna, etyczna i pedagogiczna Witołda Rubczyńskiego, Wyd. Akademii Humanistyczno-Ekonomicznej w Łodzi, Łódź 2009, s. 86.

${ }^{13}$ S. Jedynak, Etyka polska w latach 1863-1918, Wiedza Powszechna, Warszawa 1977, s. 256.

${ }^{14}$ Takie same spostrzeżenia zawiera książka K. Bochenek, L. Gawor, A. Jedynak, J. Kojkoł, Filozofia polska..., ss. 218-219. Por. R. Polak, Rubczyński Witold, w: Encyklopedia filozofii polskiej, ss. 469-471. Rubczyński miał na imię Witołd, a nie Witold. 
W. Rubczyński traktuje człowieka jako byt społeczny, który powinien starać się upowszechniać przyjaźń, altruizm i braterstwo. Uznawał, że katolik ma duchowo-religijny obowiązek walki o szlachetne ideały. Ta działalność wymaga od niego wewnętrznego i zewnętrznego wysiłku oraz podejmowania różnych czynności mających na celu uduchowienie życia ludzkiego. Z tego wyrasta przekonanie W. Rubczyńskiego, że nie ma stałego postępu ludzkości, lecz powolne przezwyciężanie trudności prowadzące do doskonalenia się jednostek i społeczeństwa. Proces ten z jednej strony unaocznia wartość sfery ducha, a z drugiej uspołecznia. Obie zaś jego zdaniem zbliżają człowieka do Boga. Istotną rolę odgrywa tu idea Boga osobowego i wiara w jego istnienie. Słusznie zauważa to Jerzy Ochmann, pisząc:

Rubczyński przedstawia trzy koncepcje Boga: pierwszą - Boga transcendentnego, drugą - Boga immanentnego w człowieku [...] i można doszukać się jeszcze trzeciej koncepcji Boga - jako idei i wartości absolutnej. Bóg, jako idea ładu oraz jako wartość bezwzględna, której powinny być poddane wszelkie wartości względne, jest prawdą absolutną, do której zmierza wszelka prawda stopniowa, uzasadniająca normy moralne. Owa idea i wartość posiadają swą energię. Moc prawdy przyciąga intelekt człowieka, a moc ładu zmusza do doskonalenia moralnego i do pokonywania przeszkód. Moc ładu góruje nad mocą fizyczną, stąd dzięki wartościom wyższym człowiek potrafi przeciwstawić się wartościom niższym ${ }^{15}$.

Trzeba zaznaczyć, że teza o Bogu jako warunku koniecznym rozwoju ludzkości, narodu, społeczeństwa jest kontrowersyjna. Może rozbudzać nacjonalizm zamiast patriotyzmu, chore ambicje zamiast szlachetnych, sławę z pobudek egoistycznych, a nie altruistycznych, fałszywe bohaterstwo zamiast bohaterstwa nadobowiązkowego. Zdając sobie sprawę z tych niebezpieczeństw, W. Rubczyński pisał:

[...] polityka, chociażby była uprawiana w najlepszej wierze i z niezłomnie szczerem przekonaniem roznamiętnia zazwyczaj bujniejsze temperamenty, a bez pewnej dozy temperamentu niepodobna być dzielnym politykiem. Toteż na tem wyższe uznanie i wdzięczność potomnych zasługują sobie owi wybitni działacze, którzy w walce o przeprowadzenie swych programów nie dają się ponieść ani zaślepić namiętnościom czy to zgoła osobistym, czy stronniczym, by skupili całą swą natężoną pracę i pieczę nad tem, co dla całości państwowego bytu z największym byłoby i najtrwalszym pożytkiem, i na tem, co dla niej jest najgroźniejsze ${ }^{16}$.

15 J. Ochmann, Melioryzm Witolda Rubczyńskiego, „Zeszyty Naukowe Uniwersytetu Jagielońskiego. Studia Religiologica” 43/2010, s. 244.

${ }^{16}$ W. Rubczyński, Etyka, t. 2, Lublin 1936, ss. 117-118 (pisownia oryginalna). 
W tym kontekście W. Rubczyński formułuje tezę, że religia jest warunkiem postępu. W poglądzie tym chodzi głównie o podkreślenie roli wiary oraz organizacji religijnych w uświadamianiu etycznej roli człowieka w państwie i narodzie. Jego zdaniem taką funkcję spełniają już wierzenia pierwotne. Pisał on:

Tymczasem nowsze badania nad wierzeniami religijnemi ludów znajdujących się na bardzo niskim szczeblu kultury, przypuszczalnie najwięcej zbliżonych do człowieka pierwotnego [...] wykazały, że u plemion czerwonoskórych [...], mieszkańców Ziemi Ognistej, dalej u Pigmejczyków [...], plemion południowo-wschodniej Australji - a więc na odległych od siebie niezmiernie punktach kuli ziemskiej i niezależnie między sobą występują wierzenia w jedną Najwyższą Istotę z atrybutami (przymiotami) wybitnie etycznymi zgodnemi z pojęciami moralnemi dzisiejszych społeczeństw kulturalnych, wypielęgnowanych przez monoteistyczne religie ${ }^{17}$.

W. Rubczyński uważał, że w historii myśli mamy do czynienia z dwoma stanowiskami dotyczącymi powstania religii. Pierwsze z nich przyjmuje, że w początkowym okresie funkcjonowania społeczeństwa człowiek był egoistą, kierującym się w swych działaniach prymitywnymi popędami seksualnymi i „stadnymi”. W związku z tym nie był zdolny do wiary w jedną istotę najwyższą, życzliwą dla ludzi, która była pierwszą przyczyną całego wszechświata. Drugie stanowisko podkreśla, że „jednobóstwo” nie jest niczyim wymysłem, ale faktem. Tak twierdzą wyznawcy monoteistycznych religii objawionych, czyli chrześcijaństwa i islamu.

Dla W. Rubczyńskiego nie jest ważne, jakie stanowisko jest prawdziwe, chociaż sympatyzował z drugim ujęciem. Ważne było to, że religie oraz kościoły, a przynajmniej niektóre z nich, oddziałują na swoich wyznawców w taki sposób, iż w ich świadomości pojawia się poczucie obowiązku, gwarantujące możliwie pokojowe współżycie i współpracę. Myśliciel ten zdawał sobie sprawę, że istnieją także „wierzenia i kulty usposabiające” do zachowań agresywnych i wrogich w stosunku do przedstawicieli innych wyznań oraz współwyznawców opuszczających wspólnotę. Ponadto istnieją religie, które schlebiają ludzkim słabostkom, takim jak pragnienie wygody i rozkoszy, lenistwo, samouwielbienie (islam). W końcu dochodzi on do wniosku, że są religie, które mniej lub bardziej wpływają na rozwój społeczno-duchowy człowieka mający na celu podporządkowanie sfery „biologiczno-gospodarczej” rezultatom myśli ${ }^{18}$.

17 Ibidem, s. 119 (pisownia oryginalna).

${ }^{18}$ Ibidem, ss. 119-121. 
Autor Etyki wymieniał religie plemienne, narodowe i państwowe oraz uniwersalistyczne. Wśród tych ostatnich wyróżniał buddyzm mający jego zdaniem charakter fatalistyczny, ograniczający dążenia człowieka do ulepszenia stosunków między ludźmi, oraz chrześcijaństwo, które głosi realizację „Królestwa Bożego na ziemi”. W. Rubczyński konstatuje, że wiele wspaniałych osiągnięć religii zostało zaprzepaszczonych wskutek działań ludzi ograniczonych. Pisał on: „Przymusem, postrachem, prześladowaniami, żądaniem wiary i posłuszeństwa na ślepo zmarnowano wiele wspaniałych owoców działania religii”" ${ }^{19}$.

Jego zdaniem religie dążące do objęcia swym zasięgiem całej ludzkości muszą wywierać na swoich wyznawców taki nacisk, aby ich działania były bezinteresowne. Nie można tego dokonać bez podnoszenia poziomu życia duchowego, bez ugruntowania w społeczeństwie przekonania, że wszyscy muszą spełniać swoje obowiązki, szczególnie w stosunku do państwa. Religia tego rodzaju musi także wzywać swoich wyznawców do wyświadczania dobra swoim nieprzyjaciołom oraz jak największej liczbie potrzebujących.

Z poglądów tych wynika, że religie współzawodniczą ze sobą nie tylko o dusze ludzi, ale także o społeczną aktywność. Muszą wychowywać ludzi tak, aby stawali się jak najlepszymi, „,najtęższymi”, najbardziej zharmonizowanymi zewnętrznie i wewnętrznie członkami wspólnoty. Chodzi tu głównie o solidarność ludzi w przezwyciężaniu wszelkich niebezpieczeństw. To ona jest gwarancją istnienia państwa i narodu. W. Rubczyński pisał:

Ale nadchodzą prędzej czy później dla każdego ludu, narodu i państwa czasy ciężkich prób przebywanych zwycięsko tylko przez społeczeństwa, których widoczna większość nie lęka się śmierci, jest zgodna w solidarnym stawianiu czoła niebezpieczeństwom. Zdolna do posłuchu dla wyłonionej z siebie władzy ma wolę mocną, zaprawioną do trudów i innych przeciwności ${ }^{20}$.

\section{Jan Hieronim Hempel}

Różne inspiracje towarzyszyły rozmyślaniom Jana Hieronima Hempla publicysty, religioznawcy, działacza rewolucyjnego i społecznego oraz współorganizatora ruchu spółdzielczego w Polsce ${ }^{21}$. W jego myśli dostrzec

${ }^{19}$ Ibidem, s. 122.

${ }^{20}$ Ibidem.

${ }^{21}$ Szerzej: A. Czajczyk, Hempel Jan Hieronim, w: Encyklopedia filozofii polskiej, t. 1, Polskie Towarzystwo Tomasza z Akwinu, Lublin 2011; A. Gross, K. Horoch, Polski słownik biograficzny, Zakład Narodowy im. Ossolińskich, Wrocław - Warszawa 1960-1961; 
można idealistyczną filozofię życia, indywidualizm, anarchizm, woluntaryzm oraz antychrześcijańskie idee humanistyczne. Sięgał on do twórczości Fryderyka Nietzschego, Georges’a Sorela, Henriego Bergsona, Georga Wilhelma Friedricha Hegla, Karola Marksa, Piotra A. Kroptkina, Williama Jamesa, Karla Kautskiego, inspirował się też hinduizmem.

Uważał, że koniecznym warunkiem stworzenia nowego (lepszego) ustroju jest moralne i duchowe odrodzenie się człowieka. Musi ono zachodzić równocześnie z przekształceniem rzeczywistości społecznej, dokonywanym przez organizacje samorządowe. Przeobrażenia społeczne należy zaczynać od siebie, od zmiany własnego ładu, moralnego przeobrażenia w duchu altruizmu, braterstwa, życzliwości i bezinteresowności. W tym celu jak pisze S. Jedynak:

[...] mocniej przeciwstawia etykę wolnych jednostek ludzkich, ludzi mocnych, etyce ludzi słabych, zależnych, podporządkowanych panom i pańskości. Ludzie mocni walczą z wszelkim podporządkowaniem. W każdym starają się dostrzec brata i zamiast nędznej filantropii ofiarują braterską pomoc i przyjaźń oraz szlachetność. Zamiast służalstwa i poniżenia siebie propagują męstwo, ofiarność, życzliwość i serdeczność (cnoty piastowskie). Każdy z tych ludzi jest bohaterem. Ideał takiego bohatera dostrzegł Hempel w literaturze starożytnych Indii, zwłaszcza w Ramajanie ${ }^{22}$.

Ze studiów nad filozofią hinduską powstała (wydana w 1914 r. w Lublinie) broszurka Bohaterska etyka Ramajany, będąca kontynuacją i rozwinięciem myśli zawartych w Kazaniach Piastowych. J.H. Hempel przeciwstawia w niej etykę „wolnych Ariów” niewolniczej etyce chrześcijańskiej, przeciwstawia Biblii epopeję bramińską o Ramie.

W pracach Kazania polskie (1907) i Kazania Piastowe (1912) przyjął on za podstawowe kategorie „życie” i „ducha”, będące rozwijającymi się czynnikami twórczymi, uwznioślającymi byt człowieka. Jak pisze S. Jedynak:

Prawdziwy człowiek - według Hempla - prowadzi życie coraz bogatsze, intensywniejsze, stawia przed sobą ideał jutra. Zwalcza wszystko, co może go ograniczyć, związać, a więc religię i systemy metafizyczne. Przeciwstawia

Z. Janota, Dzieje rodziny Hemplów - spisane we współpracy z Kazimierzem Hemplem, Warszawa 1987; L. Kamiński, Najszlachetniejszy fanatyk, Wyd. Lubelskie, Lublin 1981; W. Papiewska, Jan Hempel. Wspomnienia siostry, Warszawa 1958; R. Rosiak, O Janie Hemplu, w: J. Hempel, Listy do siostry, Lublin 1961; J. Szmyd, Jan Hempel. Idee i wartości, Warszawa 1975; J. Szmyd, Hempel Jan (1877-1937), w: idem, Wizerunki filozofów i humanistów polskich: wiek XX, Wyd. Edukacyjne, Kraków 2000.

22 S. Jedynak, Etyka w Polsce. Słownik pisarzy, Zakład Narodowy im. Ossolińskich, Wrocław - Warszawa - Kraków - Gdańsk - Łódź 1986, s. 67. 
się ideałom judeochrześcijańskim (pokora, posłuszeństwo, poprzestawanie na małym) i przeniknięty aryjskim duchem tworzy nowy ład moralny, w którym przejawia się odrodzenie moralnej natury człowieka. Człowiek jest tu pojmowany jako indywidualny duch rozwijający swój świat wewnętrzny, stwarzający i konstytuujący siebie. Ma wrogów w Bogu, gromadzie i kobiecości. Te siły zagrażają bowiem - według młodego Hempla - samodzielności moralnej indywidualnego ducha ludzkiego. Tak rozumiana etyka, której pierwszy zarys zawierają Kazania polskie, jest jego zdaniem - etyką narodową Polaków, etyką odpowiadającą duchowi polskiemu²3.

W Kazaniach polskich J.H. Hempel zwalczał wszelkie formy wiary w Boga osobowego, krzewił kult człowieka, a artysta będący jego najwyższym reprezentantem miał być twórcą nowych wartości. Głosił „religię wolną”, która była spoiwem mistycznej łączności z transcendentalną rzeczywistością duchową „nad światem”. Propagował też ideę, że lud polski ma do spełnienia wielką dziejową misję - obalenie chrześcijaństwa. Religię tę uznawał bowiem za hamulec „życia i ducha” i proponował wprowadzić w jej miejsce religię „ludzką”, nieteistyczną.

Ta wczesna koncepcja J.H. Hempla - nosząca nazwę „etyki polskiej” nie była tworem o jednolitej i zwartej strukturze, nie była też uporządkowana ani spójna. Stanowiła raczej wyraz spontanicznych, okazjonalnych reakcji, stanów i nastawień moralnych jej autora. Była wypadkową ekspresyjnych przeżyć wewnętrznych oraz dążeń ideowych człowieka o bogatej i wrażliwej osobowości. Z tego wynika jej niecałkowita spójność i zwartość oraz ogromna otwartość, a także wielowątkowość. Główną zasadą „etyki polskiej” jest wezwanie do potęgowania „życia” we wszystkich jego przejawach i dziedzinach, takich jak poznawcze, ideowe, społeczne i estetyczne oraz przyrodnicze. J.H. Hempel stwierdzając, że „Życie” to „nieustanne nowego Świata tworzenie i odkrywanie”, to „walka nieustanna”, to również „każdej nowej rzeczy tworzenie w wysiłku jak największym”, „nowych [...] prawd ukazanie”, „ku nowym formom spółżycia gromady porywanie” i dalej „nowych lądów odkrywanie i nowych maszyn tworzenie”24, chciał pobudzić i zachęcić czytelnika do twórczego, przeobrażającego rzeczywistość czynu. Chodziło mu przy tym o czyn twórczy:

[...] czynić owocnie można tylko wtedy, gdy ma się cel, gdy ma się wiarę i ideał. Z połączenia tych twierdzeń wynika następujące zasadnicze etyki polskiej zawołanie: miej cel i z siłą dąż ku niemu² ${ }^{25}$.

${ }^{23}$ S. Jedynak, Etyka polska..., ss. 260-261.

24 J.H. Hempel, Kazania polskie, Kurytyba, b.m. 1907, ss. 16, 96.

${ }^{25}$ Ibidem, s. 95. 
W Kazaniach Piastowych J.H. Hempel jeszcze bardziej przeciwstawił etykę wolnych i mocnych jednostek ludzkich etyce ludzi słabych - niewolników, podporządkowanych panom i pańskości. Ludzie mocni, walcząc z wszelkim podporządkowaniem Panu oraz Kościołowi, w każdym człowieku starają się dostrzec brata, ofiarowując braterską pomoc, przyjaźń i szlachetność. Zamiast służalstwa i poniżania się proponują cnoty piastowskie, takie jak męstwo, ofiarność, życzliwość i serdeczność, będące jednocześnie wartościami moralnymi. Każdy z nich jest bohaterem:

Bohater to istota niezależna, działająca w swym własnym imieniu; istota, nad którą żaden Pan, nikt sądzić ją uprawniony, pomyśleć się nawet nie daje. Bohater nie istnieje, sam sobą bohaterem być przestaje, gdy przypuścić, że ktoś go posłał, że działa on z czyjegoś rozkazu ${ }^{26}$.

J.H. Hempel tworzył swoją etykę wraz z całą zawartością metafizyczno-filozoficzną i ideologiczną w opozycji do etyki chrześcijańskiej. Pragnął w tej konstrukcji etycznej zawrzeć wszystko to, co było antytezą moralistyki chrześcijańskiej - jej filozofii życiowej, ideałów etycznych i światopoglądu.

Krytyce prowadzonej z niezwykłą pasją, miejscami wręcz brutalnej, poddane zostały założenia etosu biblijnego, zawarty w nim ideał człowieka, cnoty moralności chrześcijańskiej i jej zasady. Chodziło konkretnie o zinstytucjonalizowaną religię teistyczną, którą J.H. Hempel nazywał religią „boską”, i o światopogląd zwany „niewolniczym”, którego dominującą cechą jest absolutne podporządkowanie ludzkiego ,ja” Bogu transcendentnemu lub „panu” ziemskiemu. Ten światopogląd i religię J.H. Hempel uznał za najważniejsze czynniki przeciwrozwojowe, którym należy się zdecydowanie przeciwstawić w imię postępu. Na tak negatywną ocenę chrześcijaństwa wpłynęła prawdopodobnie lektura Nietzschego i innych krytyków chrystianizmu. J.H. Hempel uważał, że religia chrześcijańska i etyka kształtowały człowieka-niewolnika, niezdolnego do buntu, do rewolucyjno-romantycznej przemiany świata, niezdolnego do prawdziwie wolnościowej postawy oraz do buntu i czynu burzycielskiego.

Krytykując światopogląd „niewolniczy”, widział w nim odzwierciedlenie niewolniczej sytuacji narodu żyjącego w zależnościach wewnętrznych - od własnych kapłanów oraz zewnętrznych - od obcych władców. Nadał on idei niewolnictwa kosmiczny i transcendentny charakter. Uważał, że górujący nad człowiekiem nie tylko „pan” ziemski, ale również Bóg stwo-

${ }^{26}$ J. Hempel, Kazania Piastowe, R. Schmeer, Bielsko 1912, s. 228. 
rzyciel, Bóg właściciel, Bóg władca sprowadza człowieka do roli „raba”niewolnika ${ }^{27}$. Poglądy te wyraził w Kazaniach polskich, nie znając przypuszczalnie jeszcze zasad materializmu historycznego, akcentując jednak wyraźnie, że walka z religią teistyczną jest przejściowym etapem w batalii o zbawienie świata. Pisał on bez ogródek:

Kto chce iść w nadświaty, kto chce w nieskończoność twórczym sięgać wzrokiem, ten przede wszystkim musi Boga pokonać [...]. Póki Bóg stoi nad tobą, a nie pod tobą, póty żeś niegodny nazwać się wolnym człowiekiem [...]. Dopiero po pokonaniu Boga, po stanięciu nad nim [...] do innych przeszkód przystąpić możesz ${ }^{28}$.

Z przytoczonego fragmentu wynika, że J.H. Hempel uważał, iż chrześcijaństwo zakorzenione głęboko w umysłach naszych przodków miało niekorzystny wpływ na ich słowiańską kulturę moralną i obyczajową, spowodowało zniszczenie etosu Piastowego, osłabiło niektóre cechy słowiańskiego charakteru, takie jak ofiarność, rozmach twórczy, duma i dostojność; osłabiło chęć do walki o wolność i niepodległość narodu polskiego.

Zgodzić się trzeba z Janem Skoczyńskim, który pisze:

Jan Hempel interpretował religię w duchu bliskiego romantyzmowi mitu prometejskiego (heroizm), czego wyrazem były prace: Kazania polskie (1907) i Kazania Piastowskie (1912), w których Bóg traktowany jest w kategoriach alienacji ludzkich tęsknot i przeżyć metafizycznych. Ich połączenie z rodzimą tradycją piastowską miało prowadzić do odrodzenia autentycznej religijności (naturalnej), zbudowanej na ideałach miłości i wolności, a nie mającej swego pana i Boga (objawionej) ${ }^{29}$.

Należy jednak pamiętać, że jego poglądy ewoluowały od stanowiska krytycznego, bazującego na dość jednostronnie rozumianym nietzscheanizmie, do dużo głębszych analiz funkcji religii. Początkowo traktuje je jako wytwór jednostek wybitnych, uduchowionych, znaczących indywidualności religijnych. Następnie rozumie ich społeczne, kulturowe, historyczne i polityczne znaczenie. W ten sposób aspekt przedmiotowy zaczyna brać górę nad aspektem podmiotowym. W związku z tym krytykował on analizę religijności indywidualnej w oderwaniu od jej społecznych uwarunkowań. Dokonał też opisu różnych form religijności.

${ }^{27}$ Ibidem, ss. 135-142.

${ }_{28}$ J.H. Hempel, Kazania Piastowe, ss. 14-15.

29 J. Skoczyński, Modernizm i Młoda Polska, s. 377. 


\section{Podsumowanie}

Wydaje się, że w rozważaniach wszystkich trzech myślicieli chodziło w istocie o ukazanie znaczenia religii (duchowości), a w zasadzie wiary w kształtowaniu człowieka, dla którego najważniejszy byłby inny człowiek, a także o ukształtowanie nowego typu duchowości opartej na altruizmie. Akceptowali oni bowiem rolę „prawdziwej religijności” (chociażby świeckiej) skierowanej na inną jednostkę i społeczeństwo.

Myśliciele ci zdawali sobie sprawę, że w epoce relatywizmu nie można pominąć problematyki wolności, zarazem jednak zastrzegali, że musi być ona pełna szacunku dla przedmiotowego stanu rzeczy. Sądzili, że wolność jednostek i ład powszechny są ogniwami jednej całości ideowej.

W ich ujęciu filozofia, nie odwołując się jawnie do dogmatów, miała dać równie trwały, lecz bardziej uogólniony obraz świata, będący czymś w rodzaju kompromisu między prawdami teologii a światopoglądem ludzi uprawiających naukę współczesną.

Według nich na najwyższe uznanie zasługują jednostki wybitne, które w walce o przeprowadzenie swych programów nie dają się ponieść ani zaślepić namiętnościom osobistym czy wynikającym z uwarunkowań kulturowych. Te, które mimo dzielących ich różnic skupiają się na zagadnieniach najważniejszych dla całości państwowego bytu, hołdują zdrowemu patriotyzmowi, a nie politycznemu nacjonalizmowi.

Rozumieli, że myślenie religijne (choćby świeckiego rodzaju) dążące do objęcia swym zasięgiem całej ludzkości musi wywierać taki nacisk, aby działania człowieka były bezinteresowne. Nie można tego dokonać bez podnoszenia poziomu życia duchowego, bez ugruntowania w społeczeństwie przekonania, że wszyscy muszą spełniać swoje obowiązki, szczególnie wobec państwa. Tym samym byli oni zwolennikami stworzenia nowego (lepszego) ustroju opartego na moralnym i duchowym odrodzeniu się człowieka.

Ich ideały były głęboko humanistyczne, choć bazowały na różnych założeniach teoretycznych, ideologicznych i światopoglądowych. Człowiek stał się w nich podmiotem dziejów, choć nie oznaczało to odrzucenia założenia o istnieniu świata duchowego. Zasługują one - i wiele innych koncepcji polskiej myśli filozoficzno-społecznej - na gruntowne przebadanie, zwłaszcza w zakresie refleksji o religii. 


\section{Literatura}

Bochenek K., Gawor L., Jedynak A., Kojkoł J., Filozofia polska okresu międzywojennego. Zarys problematyki, Akademia Marynarki Wojennej, Gdynia 2013.

Bochenek K., Gawor L., Michalik-Jeżowska M., Wójtowicz R., Zarys historii filozofii polskiej, Wyd. Uniwersytetu Rzeszowskiego, Rzeszów 2013.

Borzym S., Filozofia międzywojenna (1918-1939), w: A. Walicki (red.), Zarys dziejów filozofii polskiej 1815-1918, PWN, Warszawa 1986.

Borzym S., Filozofia polska 1900-1950, Ossolineum, Wrocław - Warszawa - Kraków 1991.

Czajczyk A., Hempel Jan Hieronim, w: Encyklopedia filozofii polskiej, t. 1, Polskie Towarzystwo Tomasza z Akwinu, Lublin 2011.

Grabowski T., Filozofia poznania i metafizyka prof. Rubczyńskiego, w: Przemówienia wygłoszone ku czci śp. prof. Witolda Rubczyńskiego dnia 15 listopada 1938 r., Kraków 1939.

Gross A., Horoch K., Polski słownik biograficzny, Zakład Narodowy im. Ossolińskich, Wrocław - Warszawa 1960-1961.

Hempel J.H., Kazania Piastowe, R. Schmeer, Bielsko 1912.

Hempel J.H., Kazania polskie, Kurytyba, b.m. 1907.

Janota Z., Dzieje rodziny Hemplów - spisane we współpracy z Kazimierzem Hemplem, Warszawa 1987.

Jedynak S., Etyka polska w latach 1863-1918, Wiedza Powszechna, Warszawa 1977.

Jedynak S., Etyka w Polsce. Słownik pisarzy, Zakład Narodowy im. Ossolińskich, Wrocław - Warszawa - Kraków - Gdańsk - Łódź 1986.

Kamiński L., Najszlachetniejszy fanatyk, Wyd. Lubelskie, Lublin 1981.

Knapik T., Kultura i wartości w ujęciu Witolda Rubczyńskiego i Floriana Znanieckiego, „Studia z Filozofii Polskiej”, t. 5, pod red. M. Rembierza, K. Ślezińskiego, Bielsko-Biała - Kraków 2010.

Michalski M.A., Ku idei Królestwa Bożego - myśl filozoficzna, etyczna i pedagogiczna Witolda Rubczyńskiego, Wyd. Akademii Humanistyczno-Ekonomicznej w Łodzi, Łódź 2009.

Ochmann J., Melioryzm Witolda Rubczyńskiego, „Zeszyty Naukowe Uniwersytetu Jagielońskiego. Studia Religiologica” 43/2010.

Palacz R., Witold Rubczyński czyli filozofia polskiego spirytualizmu XIX wieku, w: idem, Klasycy filozofii polskiej, Zachodnie Centrum Organizacji, Warszawa - Zielona Góra 1999.

Papiewska W., Jan Hempel. Wspomnienia siostry, Warszawa 1958.

Polak R., Rubczyński Witold, w: Encyklopedia filozofii polskiej, t. 2, Polskie Towarzystwo Tomasza z Akwinu, Lublin 2011.

Rosiak R., O Janie Hemplu, w: J.H. Hempel, Listy do siostry, Lublin 1961.

Rozmyślania religijne na Nowy Rok, Dzień Trzech Króli, pierwszq, drugq i trzeciq niedzielę po Trzech Królach, luźne notatki, rękopisy IFiS PAN, syg. T’R 136 - T. 2, 3, s. 2, http:// rcin.org.pl [25.01.2015].

Rubczyński W., Etyka, t. 2, Lublin 1936.

Rubczyński W., Filozofia życia duchowego jego wytrzymałość, skuteczność i ład w świetle doświadczenia i krytyki, Fiszer i Majewski, Poznań 1925.

Skoczyński J., Modernizm i Młoda Polska, w: J. Skoczyński, J. Woleński, Historia filozofii polskiej, WAM, Kraków 2010. 
Szmyd J., Hempel Jan (1877-1937), w: idem, Wizerunki filozofów i humanistów polskich: wiek XX, Wyd. Edukacyjne, Kraków 2000.

Szmyd J., Jan Hempel. Idee i wartości, Warszawa 1975.

Twardowski K., O filozofii średniowiecznej wykładów sześć, nakład H. Altenberga, Lwów 1910

Twardowski K., Psychologia wobec fizjologii i filozofii, „Przewodnik Naukowy i Literacki” $1 / 1897$.

Woleński J., Filozoficzna szkoła lwowsko-warszawska, PWN, Warszawa 1985.

Woleński J., Twardowski Kazimierz, w: Encyklopedia filozofii polskiej, t. 2, Polskie Towarzystwo Tomasza z Akwinu, Lublin 2011. 